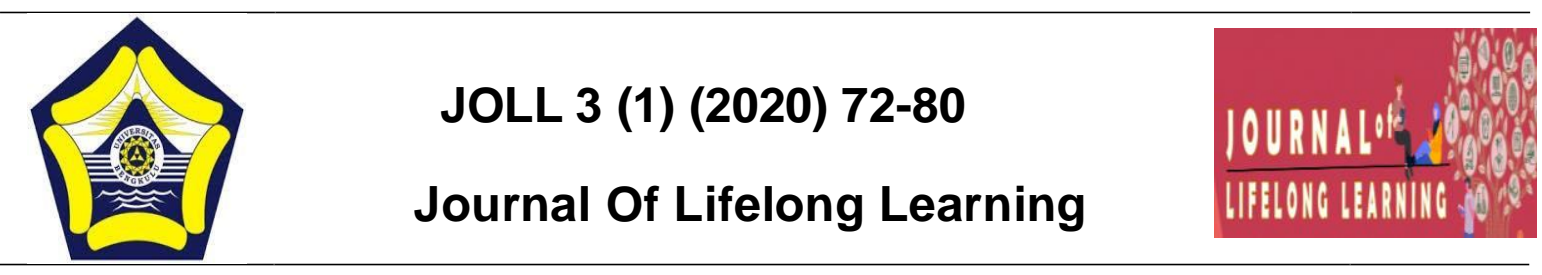

\title{
Cara Guru Ngaji Dalam Meningkatkan Membaca Al-Qur'an Majelis Taklim Aisyiyah Kabupaten Seluma
}

\author{
Riza Jayanti ${ }^{1}$, Sofino², Agus Zainal ${ }^{23}$ \\ ${ }^{1}$ Riza Jayanti, Universitas Bengkulu, Indonesia, Rizajayanti09@yahoo.com \\ ${ }^{2}$ Sofino, Universitas Bengkulu, Indonesia, sopino@gmail.com \\ ${ }^{3}$ Agus Zainal, Universitas Bengkulu, Indonesia, aguszainal82@yahoo.com
}

\begin{abstract}
The research is aimed to describe the eforts of reciting Al-Quran teacher in increasing reading Al-Quran ability of women of taklim souncil Aisiyah RT 03 at Masmambang village Talo Subdistrict Seluma Regency. Subjects in this research are the chief and reciting Al-Quran teacher of Taklim Souncil Aisiyah, and 2 studying citizens of Taklim Souncil Aisiyag. Technique of collecting the data uses interview, observation, and documentation. Analyzing the data is done with these following steps: data reduction, data presentation, and drawing conclusion. Validation of the data uses triangulation technique, begin from subject triangulation, time triangulation, and technique triangulation. The result of the research shows that method that is used by Mrs. Sampurna as reciting Al-Quran teacher of Taklim Souncil Aisiyah is Iqra' Method in which by this method, it can help Mrs. Sampurna in doing teaching and learning process of reciting Al-Quran at Aisyah Shelter. The implementation is reciting Al-Quran directly by turns. If there is wrong reading, it will be admonished by the teacher and is corrected the reads directly and with method and the implementation which Mrs. Sampurna does gets good responds from women of Taklim Souncil Aisiyah after they end Al-Quran. They are taught Tajwid understanding, if there is reciting from another place, they also follow the reciting in order to improving the ability of reciting Al-Quran too. The infrastructures at Taklim Souncil Aisiyah are still suitable and enough to facilitate women of Taklim Souncil Aisiyah. The proponent factor of Mrs. Sampurna as reciting Al-Quran teacher of Taklim Souncil Aisiyah and Mrs. Sukarsih and also Ibu Rusni is the wants and big spirit for studying of reciting Al-Quran and the obstacle factor is the infrastructure which is the building of shelter as the place of women of taklim souncil Aisiyah for studying the Alquran reciting has been brittle and broken.
\end{abstract}

Keywords: reciting Al-Quran teacher, effort, Taklim Souncil, reading Al-Quran

(C2020 DeptofNonformalEducationUNIB ISSN : 2715-9809

$\square$ Addresscorrespondence:

Jl.W.R.Supratman,KandangLimun, MuaraBangkaHulu, KotaBengkulu,Bengkulu38371

(C2020 Dept Of Nonformal Education UNIB Online ISSN : 2715-9809 


\section{Pendahuluan}

Dilihat dari latar belakang masalah, maka rumusan masalah secara umum dalam penelitian ini yaitu Upaya Guru Ngaji Dalam meningkatkan kemampuan membaca Al-Qur'an Ibu-Ibu Majelis Taklim Aisiyah RT 03 Di Desa Masmamabang Kecamatan Talo Kabupaten Seluma, sedangkan secara khusus rumusan masalah dalam penelitian ini yaitu : 1)Bagaimanakah Metode Guru Ngaji dalam Upaya Meningkatkan Kemampuan Membaca Al-Qur'an Ibu-Ibu Majelis Taklim Aisyiyah RT 03 Di Desa Masmambang Kecamatan Talo Kabupaten Seluma ? 2)Bagaimanakah Upaya Pengembangan yang Dilakukan Guru Ngaji Majelis Taklim Aisiyah dalam Meningkatkan Kemampuan Membaca Al-Qur'an IbuIbu Majelis Taklim Aisyiyah Rt 03 Di Desa Masmambang Kecamatan Talo Kabupaten Seluma ? 3)Apakah Faktor Pendukung dan Penghambat dalam Upaya Meningkatkan Kemampuan Membaca Al-Qur'an Ibu-Ibu Majelis Taklim Aisyiyah RT 03 Di Desa Masmambang Kecamatan Talo Kabupaten Seluma.

Secara umum tujuan penelitian ini adalah untuk mengetahui Upaya Guru
Ngaji Dalam Meningkatkan Kemampuan Membaca Al-Qur'an Ibu-Ibu Majelis Taklim Aisyiyah RT 03 Di Desa Masmambang Kecamatan Talo Kabupaten Seluma , secara khusus tujuan yang ingin dicapai dalam penelitian ini adalah Bagaimana Upaya Guru Ngaji Dalam Meningkatkan Kemampuan Membaca Al-Qur'an Ibu-Ibu Majelis Taklim Aisyiyah RT 03 Di Desa Masmambang Kecamatan Talo Kabupaten Seluma,sebagai berikut :1)Untuk mengetahui metode guru ngaji dalam upaya meningkatkan kemampuan membaca Al-Qur'an Ibu-Ibu Majelis Taklim Aisiyah RT 03 Di Desa Masmambang Kecamatan Talo Kabupaten Seluma.2)Untuk mengetahui Upaya Pengembangan yang Dilakukan Guru Ngaji Majelis Taklim Aisyiyah dalam Meningkatkan Kemampuan Membaca Al-Qur'an Ibu-Ibu Majelis Taklim Aisyiyah Rt 03 Di Desa Masmambang Kecamatan Talo Kabupaten Seluma.3)Untuk Mengetahui Faktor Pendukung dan Penghambat dalam Upaya Meningkatkan Kemampuan Membaca Al-Qur'an Ibu-Ibu Majelis Taklim Aisyiyah RT 03 Di Desa Masmambang Kecamatan Talo Kabupaten Seluma. 
Menurut Pupuh Fathurrohman dan Sobry Sutikno (2011 : 55 ) secara harfiah metode berarti cara. Dalam pemakaian yang umum, metode diartikan sebagai suatu cara atau prosedur yang dipakai untuk mencapai tujuan tertentu.

Ada beberapa metode dalam pemebelajaran Al-Qur'an,yaitu:

1. Metode Iqro' Metode iqro' adalah suatu metode membaca Al-Qur'an yang menekankan langsung pada latihan membaca. Adapun buku panduan iqro' terdiri dari 6 jilid di mulai dari tingkat yang sederhana, tahap demi tahap sampai pada tingkatan yang sempurna.

Metode iqro' ini dalam prakteknya tidak mem-butuhkan alat yang bermacam-macam, karena ditekan-kan pada bacaannya (membaca huruf Al-Qur'an dengan fasih). Bacaan langsung tanpa dieja. Artinya tidak diperkenalkan namanama huruf hijaiyah dengan cara belajar siswa aktif (CBSA) dan lebih bersifat individual.

\section{Metode Al-Baghdad}

Metode Al-Baghdady adalah metode tersusun (tarkibiyah), maksudnya yaitu suatu metode yang tersusun secara berurutan dan merupakan sebuah proses ulang atau lebih kita kenal dengan sebutan metode alif, $b a^{\prime}, \quad t a^{\prime}$. Metode ini adalah metode yang paling lama muncul dan metode yang pertama berkembang di Indonesia.

\section{Metode An-Nahdhiyah}

Metode An-Nahdhiyah adalah salah satu metode membaca Al-Qur'an yang muncul di daerah Tulungagung, Jawa Timur. Metode ini disusun oleh sebuah lembaga pendidikan Ma'arif Cabang Tulungagung. Karena metode ini merupakan metode pengembangan dari metode Al-Baghdady, maka materi pembelajaran Al-Qur'an tidak jauh berbeda dengan metode Qira'ati dan Iqro'. Dan perlu diketahui bahwa pembelajaran metode ini lebih ditekankan pada kesesuaian dan keteraturan bacaan dengan ketukan atau lebih tepatnya pembelajaran AlQur'an pada metode ini lebih menekankan pada kode "Ketukan".

\section{Metode Jibril}

Terminology (istilah) metode jibril yang digunakan sebagai nama dari pembelajaran Al-Qur'an yang diterapkan di PIQ Singosari Malang, 
adalah dilatar belakangi perintah Allah

SWT kepada Nabi Muhammad SAW

untuk mengikuti bacaan Al-Qur'an

yang telah diwahyukan melalui

malaikat Jibril. Menurut KH. M.

Bashori Alwi (dalam Taufiqurrohman) sebagai pencetus metode jibril, bahwa teknik dasar metode jibril bermula dengan membaca satu ayat atau lanjutan ayat atau waqaf, lalu ditirukan oleh seluruh orang-orang yang mengaji. Sehingga mereka dapat menirukan bacaan guru dengan pas. Metode jibril terdapat 2 tahap yaitu tahqiq dan tartil.

\section{Metode Qiro'ati}

Metode Qiro'ati disusun oleh Ustadz H. Dahlan Salim Zarkasy pada tahun 1986 bertepatan pada tanggal 1 Juli. H.M Nur Shodiq Ahrom (sebagai penyusun didalam bukunya "Sistem Qa'idah Qira'ati" Ngembul, Kalipare), metode ini ialah membaca Al-Qur'an yang langsung memasukkan dan mempraktek-kan bacaan tartil sesuai dengan qa'idah ilmu tajwid sistem pendidikan dan pengajaran metode Qira'ati ini melalui system pendidikan berpusat pada murid dan kenaikan kelas/jilid tidak ditentukan oleh bulan/tahun dan tidak secara klasikal, tapi secara individual (perseorangan).

Menurut Morris dalam Sudjana (2010:327) pengembangan adalah upaya memperluas atau mewujudkan potensi-potensi,membawa suatu keadaan yang lebih lengkap,lebih luas,lebih besar,atau lebih baik,memajukan sesuatu dari yang lebih awal kepada yang lebih akhir atau dari yang sederhana kepada tahapan perubahan yang lebih baik.

Pendidikan orang dewasa (Adult Education) adalah pendidikan yang disajikan untuk membelajarkan orang dewasa,Unesco (1976) mendefinisikan pendidikan orang dewasa sebagai berikut:

Pedidikan orang dewasa merupakan seluruh proses pendidikan yang terorganisasi dengan berbagai bahan belajar,tingkatan,dan metoda,baik bersifat resmi maupun tidak, meliputi upaya kelanjutan atau perbaikan pendidikan yang diperoleh dari sekolah, akademi, universitas, atau magang.

\section{Metode}

Penelitian ini dilaksanakan dengan menggunakan metode kualitatif, karena permasalahan pada penelitian 
ini bukan yang berkenaan dengan angka-angka tetapi, mendeskripsikan dan menggambarkan tentang Upaya Guru Ngaji Dalam Meningkatkan Kemampuan MembacaAl-Qur'an IbuIbu Majelis Taklim Aisiyah Rt 03 Di Desa Masmambang Kecamatan Talo Kabupaten Seluma. Sasaran pada penelitian ini adalah guru ngaji Majelis Taklim Aisyiyah sekaligus ketua Majelis Taklim Aisyiyah , IbuIbu Majelis Taklim. Adapun penelitian ini dilaksanakan mulai dari tanggal 05 juni $\quad$ s.d 05 Juli 2017. Teknik pengumpulan data menggunakan teknik wawancara, observasi dan dokumentasi. Selanjutnya untuk teknik validitas data menggunakan reduksi data, penyajian data dan penarikan kesimpulan. Dan untuk keabsahan data pada penelitian ini menggunakan triangulasi subjek, tiangulasi waktu, dan triangulasi teknik.

\section{Pembahasan Hasil Penelitian}

Sesuai dengan hasil penelitian yang dilakukan pnelitian terhadap subjek penelitian yaitu Ibu Sampurna,Ibu Sukarsih dan Ibu Rusni yang berhubungan dengan Upaya Guru Ngaji Dalam Meningkatkan Kemampuan Membaca Al-Qur'an Ibu-Ibu Majelis
Taklim Aisyiyah Rt 03 Di Desa Masmambang Kecamatan Talo Kabupaten Seluma,sehingga dapat dijelaskan melalui pembahasan yang didasarkan atas rumusan masalah dan tujuan penelitian,yang terdapat pada BAB I,yaitu sebagai berikut:

a. Berdasarkan hasil penelitian bahwa metode yang digunakan oleh Ibu Sampurna Selaku Guru Ngaji Majelis Taklim Aisyiyah adalah metode iqra',yang dengan metode iqra' ini dapat membantu Ibu Sampurna dalam proses belajar mengajar mengaji dengan cara penerapannya adalah dengan cara ibu-ibu Majelis Taklim langsung membaca alqur'an bukan dengan hafalan

Jika ada kesalahan dalam pembacaan oleh warga belajar maka Ibu Sampurna langsung menegur dan membenahi bacaan tersebut secara langsung saat proses belajar mengaji dilakukan,dengan metode Iqra' serta penerapannya Ibu Sampurna mendapatkan respon yang baik dari Ibu-Ibu Majelis Taklim serta metode yang digunakan oleh ibu Sampurna memiliki kelebihan yakni Ibu-ibu majelis taklim lebih cepat dan mudah paham dalam membaca alqur'an dan 
kekurangannya adalah Ibu Sampurna belum mengajarkan tajwid terlebih dahulu.

Menurut Pupuh Fathurrohman dan Sobry Sutikno (2011: 55) secara harfiah metode berarti cara.dalam pemakaian yang umum,metode di artikan sebagai suatu cara atau prosedur yang di pakai untuk mencapai tujuan tertentu.

Berdasarkan hasil temuan peneliti di lapangan da teori yang ada,dapat disimpulkan bahwa metode yang digunakan Ibu Sampurna Selaku Guru Ngaji Majelis Taklim Aisyiyah adalah metode Iqra',dengan metode iqra' ini dapat membantu proses belajar mengajar ngaji Ibu-ibu Majelis Taklim Aisyiyah dengan cara penerpannya Ibu-ibu Majelis Taklim Aisyiyah langsung membaca alqur'an secara bergantian, jika ada bacaan yang salah Ibu Sampurna langsung menegur dan membenahi bacaan yang salah,dengan metode Iqra' dan penerapannya dengan langsung membaca Al-Qur'an Ibu Sampurna mendapat respon yang baik dari Ibu-Ibu Majelis Taklim Aisyiyah.

b.Pengembangan Majelis Taklim Aisyiyah Dalam Upaya Meningkatkan Kemampuan Membaca Alqur'an IbuIbu Majelis
Aisyiyah.Berdasarkan hasil penelitian di lapangan bahwa pengembangan Majelis taklim Aisyiyah terhadap potensi warga belajar atau Ibu-Ibu Majelis Taklim Aisyiyah adalah setelah mereka khatam Al-Qur'an mereka diberikan pemahaman tajwid dan jika ada pengajian di tempat lain mereka juga ikut pengajian tersebut gunanya juga untuk mengembangkan potensi warga belajarnya .

Menurut Morris dalam Sudjana (2010:327) pengembangan adalah upaya memperluas atau mewujudkan potensi-potensi,membawa suatu keadaan yang lebih lengkap,lebih luas,lebih besar,atau lebih baik,memajukan sesuatu dari yang lebih awal kepada yang lebih akhir atau dari yang sederhana kepada tahapan perubahan yang lebih baik.

Berdasarkan hasil temuan penelitian di lapangan dan teori yang ada dapat disimpulkan pengembangan potensi Ibu-Ibu Majelis Taklim Aisyiyah setelah mereka khatam alqur'an maka Ibu Sampurna mengajarkan tentang pemahaman tajwid, jika ada pengajian di tempat lain mereka juga ikut pengajian tersebut gunanya juga untuk 
mengembangkan potensi warga belajarnya.

$\begin{array}{lcr}\text { 3.Faktor } & \text { Pendukung } & \text { Dan } \\ \text { Penghambat } & \text { Dalam } & \text { Upaya }\end{array}$

Meningkatkan Kemampuan Membaca Alqur'an Ibu-Ibu Majelis Taklim Aisyiyah. Berdasarkan hasil penelitian di lapangan diketahui bahwa yang menjadi factor pendukung bagi Ibu Sampurna Selaku Guru Ngaji Majelis Taklim Aisyiyah dan Ibu Sukarsih dan Ibu Rusni selaku warga belajar Majelis Taklim Aisyiyah adalah keinginan dari diri sendiri dan semangat yang untuk belajar ngaji disamping itu keluarga serta warga belajar Majelis Taklim Aisyiyah juga ikut mendukung,sedangkan yang menjadi factor penghambat pendukung bagi Ibu Sampurna Selaku Guru Ngaji Majelis Taklim Aisyiyah dan Ibu Sukarsih dan Ibu Rusni selaku warga belajar Majelis Taklim Aisyiyah adalah keadaan bangunan Musholla yang sudah rapuh dan sudah banyak yang rusak kalau hujan airnya seringkali masuk ke dalam Musholla.

Berdasarkan hasil temuan peneliti di lapangan dapat disimpulkan bahwa yang menjadi faktor pendukung dari Guru Ngaji dan warga belajar Majelis
Taklim Aisyiyah adalah keinginan yang kuat yang didukung juga oleh keluarga untuk belajar mengaji sedangkan factor penghambatnya adalah keadaan bangunan Musholla yang sudah rapuh dan sudah banyak yang rusak kalau hujan airnya seringkali masuk ke dalam Musholla.

\section{PENUTUP}

\section{Kesimpulan}

Sesuai dengan permasalahan, tujuan, dan pembahasan, maka dapat disimpulkan sebagai berikut:

\section{Metode}

Metode yang digunakan Ibu Sampurna selaku guru ngaji Majelis Taklim Aisyiyah adalah metode Iqra'. Ibu Sampurna melakukan penerapan metode Iqra' dengan langsung membaca Al-Qur'an. Dengan metode dan penerapan yang digunakan Ibu Sampurna selaku guru ngaji, Ibu-Ibu Majelis Taklim Aisyiyah lebih cepat dan mudah paham dalam membaca AlQur'an.

\section{Pengembangan}

Pengembangan potensi yang dilakukan Ibu Sampurna selaku guru ngaji Majelis Taklim Aisyiyah dalam meningkatkan kemampuan membaca Al-Qur'an adalah setelah mereka khatam Al- 
Qur'an Ibu-Ibu Majelis Taklim Aisyiyah diajarkan ilmu tentang pemahaman Tajwid, Disamping itu selain Ibu-Ibu Majelis Taklim Aisyiyah diajarkan ilmu tentang pemahaman Tajwid Ibu-Ibu Majelis Taklim Aisyiyah juga mengikuti pengajian di tempat atau Majelis Taklim lain.

\section{Factor pendukung dan penghambat}

Bahwa yang menjadi faktor pendukung bagi Ibu Sampurna Selaku Guru Ngaji Majelis Taklim Aisyiyah adalah keinginan dari diri sendiri dan semangat yang kuat untuk belajar ngaji disamping itu keluarga serta warga belajar Majelis Taklim Aisyiyah juga ikut mendukung,sedangkan yang menjadi factor penghambat bagi Ibu Sampurna Selaku Guru Ngaji Majelis Taklim Aisyiyah adalah keadaan bangunan Musholla yang sudah rapuh dan sudah banyak yang rusak sehingga kalau hujan airnya seringkali masuk ke dalam Musholla .

\section{Referensi}

Adisusilo Sutarjo. 2014. Pembelajaran Nilai-nilai Karakter Konstruktivisme Dan VCT Sebagai Inovasi Pendekatan Pembelajaran Afektif. Jakarta:PT RajaGrafindo Pers.
Departemen agama republik Indonesia. 1993. Alqur'an dan terjemahannya. Semarang: CV .Alwaah

Emzir. 2014.

Metodologi Peneltian Kualitatif: analisis data. Jakarta:PT RajaGrafindo

PersadaFathurrohman, Sutikno. 2011. Strategi Belajar Mengajar Melalu Penananaman Konsep Umum \& Konsep Islami. Bandung : PT Refika Aditama.

Gunawan Imam. 2013. Metode Penelitian Kualitatif: Teori dan praktik. Jakarta:Bumi Aksara.

Hanafiah Nanang. 2010. Konsep Strategi Pembelajaran.Bandung: PT Refika Aditama

Jauhari Heri. 2008. Fikih Pendidikan. Bandung : PT Remaja Rosdakarya

Makbuloh Deden. 2013. Pendidikan Agama Islam Arah Baru Pengembangan Ilmu Dan Kepribadian Di Perguruan Tinggi. Jakarta : PT Raja Grapindo Persada

Muhsin $\quad$ MK. 2009. Manajemen Majelis Taklim. Jakarta: Pustaka Intermasa

Munjin Nasih. 2009. Pendidikan Agama Islam Metode Dan Taknik Pembelajaran. Bandung: PT Refika Aditama 
Nata Abuddin. 2012. Sejarah Sosial Intelektual Islam. Jakarta : Ptraja Grapindo Persada

Notoatmodjo Soekidjo. 2009. Pengembangan Sumber Daya Manusia. Jakarta:Rineka Cipta

Sudjana. 2001. pendidikan luar sekolah: Wawasan, Sejarah perkembangan, Falsafah \& Teori Pendukung, serta Asas. Bandung : PT Remaja Rosdakarya

Sudjana. 2008. Evaluasi Program Pendidikan Luar Sekolah Untuk Pendidikan Nonformal Dan Pengembangan Sumber Daya Manusia. Bandung : PT Remaja Rosdakarya

Sudjana. 2010. Manajemen program pendidikan Bandung : Falah Production

Sukardi. 2011. Evaluasi Pendidikan : Prinsip Dan Operasionalnya. Jakarta : Bumi Aksara

Syaifurahman. 2013. Manajemen Dalam Pembelajaran. Jakarta : PT Indeks.

(http://qashthaalhikmah.blogspot.c o.id/2010/o1/macam-macammetode-pembelajaran-al.html) 